\title{
Comparative Study on the Performance of Coriander Genotypes under Receding Soil Moisture Regimes in Rainfed Vertisols
}

\author{
Giridhar Kalidasu ${ }^{1 *}$, C. Sarada ${ }^{2}$, S. Surya Kumari ${ }^{1}$ and L. Naram Naidu ${ }^{3}$ \\ ${ }^{1}$ All India Coordinated Research Project on Spices \\ ${ }^{2}$ AICRP on Vegetable Crops, ${ }^{3}$ Chillies Improvement Scheme, Dr. Y. S. R. Horticultural University Horticultural Research \\ Station, Lam, Guntur, Andhra Pradesh (522 034), India
}

\section{Article History}

Manuscript No. AR1547

Received in $27^{\text {th }}$ February, 2016

Received in revised form $4^{\text {th }}$ April, 2016

Accepted in final form $6^{\text {th }}$ April, 2016

\section{Correspondence to}

"E-mail: gkalidasu@yahoo.com

\section{Keywords}

Coriander, drought, moisture stress, crop improvement

\begin{abstract}
Coriander is grown widely as a rainfed crop in India. Rainfed farming situation poses the serious problem of moisture stress during the crop growth period, which changes the crop phenology and severely affects grain yield. Understanding the behaviour of coriander under receding soil moisture regime helps to build strategies to improve the crop or manage the crop. Keeping this in view, a study was conducted to know the behavior of ten genotypes under two naturally receding soil moisture regimes (low lying and upland) in rainfed vertisols. Moisture stress (Stress index $=0.36$, moderate stress) affected the number of umbels, green leaves, biomass and yield, indicating the receding sink under mid-season moistures stress. Among the genotypes evaluated, LCC-150, LCC-143 and LCC-200 were tolerant and may be used in crop improvement programmes for developing drought tolerant varieties that are suitable for rainfed farming. Among several drought indices evaluated, KiSTI values can be utilized for successful discrimination of drought tolerant lines as these are clearly associated with performance of the genotypes in non-stressed and stressed conditions. Physiological drought tolerant parameters were useful as genotypes ability to with stand drought could be attributed specific traits. The genotype LCC-143 was positively associated with high specific leaf weight, LCC-150 with low excised leaf water loss and rate of excised leaf water loss and LCC-200 with high Chlorophyll stability index and water potential of leaves. In view of the large swathes of rainfed areas in India, it is very important to focus on moisture stress related studies as two pronged approach to fight against drought and certain extreme events of climate change.
\end{abstract}

\section{Introduction}

Coriander (Coriandrum sativum L.) is the most important of the seed spice crops grown in India. It is grown in 0.553 mha with a total production of $0.462 \mathrm{mt}$ (National Horticulture Board, 2015) in India. The crop is grown in more than twenty states in India. It is grown as a winter (Rabi) crop both under rainfed conditions in vertisols and irrigated conditions in aridisols, alfisols and ultisols. About half the coriander area in the country is rainfed and $\sim 45 \%$ of the total coriander production comes from the rainfed regions. The states of Madhya Pradesh, Andhra Pradesh, Maharashtra, Gujarat, Bihar, Odisha, Telangana, Tamil Nadu and Kota, Burundi regions of Rajasthan constitute the major rainfed coriander growing bowl in India. These areas are periodically affected by moisture stress and drought. The average productivity of the rainfed coriander in the country is only $\sim 450 \mathrm{~kg} \mathrm{ha}^{-1}$ which is only $38 \%$ of the productivity from irrigated are as $\left(\sim 1200 \mathrm{~kg} \mathrm{ha}^{-1}\right)$. The productivity of coriander in the Madhya Pradesh, which is the prime rainfed coriander area, is very low ( $\left.428 \mathrm{~kg} \mathrm{ha}^{-1}\right)$ as compared to national average (795 $\mathrm{kg} \mathrm{ha}^{-1}$ ) productivity (Yadava, 2015). Low rainfall in growing season had highly detrimental effect on crop growth and yield of coriander (Weiss, 2002). Carrubba et al. (2006) reported a significant dependence of coriander yields on precipitation (linear correlation coefficient $\mathrm{r}=0.93$ ) during plant growth. In a dry year, dominated by reduced rainfall and soil moisture status, 31 to $49 \%$ reduction in yield was reported in coriander (Nowak and Szemplinski, 2014). Deficient rainfall and soil moisture stress in the growing season was reported to be detrimental to the production of coriander (Rzekanowski et al., 2008) in a grey-brown podzolic soil (soil of quality class IIIa, and of good-wheat-soil-complex). Moniruzzaman 
et al. (2013) demonstrated that the water requirement of the coriander depends much on the climatic and soil conditions. In semi-arid Mediterranean regions (Sicily) rainfed conditions at autumn seeding resulted in low seed yield $\left(581.3 \mathrm{~kg} \mathrm{ha}^{-1}\right)$ and biomass (970.6 kg ha $\left.{ }^{-1}\right)$ of coriander (Carrubba et al., 2006). India ranks first among the rainfed agricultural countries in terms of both extent ( $86 \mathrm{mha}$ ) and value of produce (Sharma et al., 2006). These areas have limited access to irrigation, about one third of these regions get sufficient water for irrigation through precipitation or canals. In addition to this, the crop is being considered very sensitive to climate change (Rashed and Darwesh, 2015); Singh et al. (2015) called for urgent relook at the strategies to meet these extreme events triggered by the climate change. The low productivity in the rainfed coriander is a reflection of the vagaries in the rainfed production of the crop and may further dip due to uncertain climatic events such as reduced precipitation and drought. The crop usually suffers from the occurrence of moisture stress in all the areas of rainfed production and in the all the stages of its phenology. In such a scenario, measures to mitigate the drought, water harvesting and reuse, measures to improve harvest index and micro-irrigation play vital role in improving the productivity of the crop. In such scenario, where droughts are inevitable, animportant strategy in drought managementis development of drought tolerant, drought adaptive and drought resistant varieties. The objective development of drought tolerant/ adaptive/resistant varieties is as elusive as far as now in coriander. Systematic understanding of the distribution and spread of the crop, crop phenology, crop physiology, cropsoil-water relationship, crop-weather relationship, and genetic variability is of immense importance. These aspects project the available options and approaches to crop improvement. The present study was initiated to evaluate the behaviour of certain drought tolerant lines which were identified using physiologically important traits for drought tolerance.

\section{Materials and Methods}

The experiment was conducted during the Rabi season of the year 2008-09. The study was carried out in vertisols under the residual soil moisture regime at Horticultural Research Station, Lam, Guntur ( $16^{\circ} 18^{\prime} \mathrm{N}$ and $80^{\circ} 29^{\prime}$ E longitude). In this study, eight genotypes along with two popular varieties as checks were evaluated in two different soil moisture regimes in separate blocks.

\subsection{Experimental plot, soil, season and plant material}

A plot with uniform soil was selected. An abrupt rise of soil by $10 \mathrm{~cm}$ was created using lasor guided leveler in the previous season for creating a differential soil moisture gradient in the receding soil moisture regime, thus creating upland and low land effects in sub-plots of the test site. A $2 \mathrm{~m}$ border was kept between the two plots while raising the experimental crop. Black gram followed by maize was raised in Kharif and Rabi respectively in the plot after leveling to stabilize the soil physico-chemical conditions in the previous season. The soil type at this location is clayey soil; vertisols of the humid tropics, with $\mathrm{pH}$ 8.0. The Bulk density was $1.22 \mathrm{~g} \mathrm{~cm}^{-3} \mathrm{~g} \mathrm{~cm}^{-3}$, Water Holding Capacity was $47 \%$ and Hydraulic conductivity was $1.4 \mathrm{~cm} \mathrm{hour}^{-1}$. The soil was medium in available $\mathrm{N}$, medium in available $\mathrm{P}_{2} \mathrm{O}_{5}$ and high in exchangeable $\mathrm{K}_{2} \mathrm{O}$. The recommended dose of fertilizers $30 \mathrm{~kg} \mathrm{~N}, 40 \mathrm{~kg} \mathrm{P}_{2} \mathrm{O}_{5}$, $\mathrm{K}_{2} \mathrm{O}$ applied as basal dose and necessary cultural operations were taken up periodically in the experimental field. The meteorological data of Rabi season is given in Table 1. The test entries were collected from AICRP on Spices, Guntur which were already reported to have containing certain degree of drought tolerance. Two popular varieties i.e. Sadhana and Swathi were included as checks in the study.

\subsection{Raising of crop and data collection}

Each plot contained 8 rows with spacing of $30 \mathrm{~cm}$ between rows and $10 \mathrm{~cm}$ between two plants. The sowing of the crop was taken immediately after the cessation of the rains in Rabi ( $3^{\text {rd }}$ of November). Data was recorded on plant height, number of primary branches, number of secondary branches, number of umbels, number of umbellets per umbel, number of fruits per umbel, days taken to $50 \%$ flowering, days taken to maturity and yield. The soil moisture was monitored throughout the crop phenology using the gravimetric method propounded by Reynolds (1970) at $15 \mathrm{~cm}$ and $30 \mathrm{~cm}$ depths. At each date of sampling, two soil samples were collected randomly in each genotype plot, covering both stressed and unstressed plots. Thus a total of 80 soil samples were collected at each date of sampling. Soil sampling was done at 19, 27, 35, 44, 47, 62, 70,79 and 88 DAS to draw a valid soil moisture scenario. The mean soil moisture percentage arrived at two depths was used to interpret the results. Grain yield ( $\mathrm{g}$ five plants ${ }^{-1}$ ) of genotypes under both moisture non-stress (Yp) and moisture stress (Ys) plots were used to calculate stress tolerance/resistance indices. Fifteendrought tolerance indices were calculated as per the Table 2 given below.

The physiological drought parameters Relative Water Content (RWC) was measured using the method suggested by Barrs and Weatherley (1962). The Specific Leaf Weight was estimated using the method suggested by Pearce et al. (1969). Leaf thickness was estimated from surrogate methodology from Leaf Dry Matter Content, as suggested by (Vile et al., 2005). Water potential of leaves (LWP) was measured by using WESCOR's water potential system (Wescor PSYPRO) and expressed in mPasacals. SPAD Chlorophyll Meter Reading (SCMR) was 


\begin{tabular}{|c|c|c|c|}
\hline Stress index & Formula & $\begin{array}{l}\text { Remarks and desirability for } \\
\text { tolerance }\end{array}$ & Reference \\
\hline Stress intensity (SI) & {$[-(\bar{Y} s / \bar{Y} p)]$} & High values desirable. & Fisher and Maurer, 1978. \\
\hline $\begin{array}{l}\text { Stress susceptibility index } \\
\text { (SSI) }\end{array}$ & {$[-(Y s / Y p)] / S I$} & $\begin{array}{l}<1 \text { are more tolerant, lower values } \\
\text { preferred. }\end{array}$ & \\
\hline Stress tolerance index (STI) & {$[(Y p) x(Y s) /(\overline{Y p}) 2]$} & High value. & Fernandez, 1992. \\
\hline $\begin{array}{l}\text { Geometric mean productivity } \\
\text { (GMP) }\end{array}$ & $\sqrt{ }\left(\left(Y_{s} \times Y_{p}\right)\right)$ & High value. & Schneider et al., 1997. \\
\hline Harmonic mean (HARM) & {$\left[2\left(Y p x^{*} Y_{s}\right)\right] /\left[Y_{p}+Y_{s}\right]$} & High value. & \\
\hline Tolerance index (TOL) & $(Y p-Y s)$ & Low value. & Rosielle and Hamblin, \\
\hline Mean productivity (MP) & $(Y p+Y s) / 2$ & High value. & 1981. \\
\hline Relative drought index (RDI) & $\left(Y_{s} / Y_{p}\right) /\left(\overline{Y_{S}} / \bar{Y}_{p}\right)$ & High value. & vonHofler et al., 1941. \\
\hline Yield index (YI) & $(Y s) /(\bar{Y} s)$ & High value. & Gavuzziet al., 1997. \\
\hline Drought resistance index (DI) & $\left(Y_{S} \times\left(Y_{S} / Y_{p}\right)\right) / \bar{Y}_{S}$ & High value. & Lan, 1998. \\
\hline Yield stability index (YSI) & $Y_{S} / Y_{p}$ & $\begin{array}{l}\text { High values indicate high stability } \\
\text { under stress and non-stress conditions. }\end{array}$ & $\begin{array}{l}\text { Bouslama and Schapaugh, } \\
1984 .\end{array}$ \\
\hline $\begin{array}{l}\text { Stress susceptibility } \\
\text { percentage index (SSPI) }\end{array}$ & {$[(Y p-Y s) / 2(\overline{Y p})] \times 100$} & $\begin{array}{l}\text { Low values indicate stability over } \\
\text { stress and non-stress environments. }\end{array}$ & Moosavi et al., 2008. \\
\hline $\begin{array}{l}\text { Stress non-stress production } \\
\text { index (SNPI) }\end{array}$ & $\begin{array}{l}{\left[{ }^{3} \sqrt{ }((Y p+Y s) /(Y p-Y s))\right]} \\
x \\
{\left[3 \sqrt{ }\left(Y p \times Y s \times Y_{s}\right)\right]}\end{array}$ & $\begin{array}{l}\text { High values indicate relatively resistant } \\
\text { genotypes with relatively stable and } \\
\text { high yield instress and non-stress } \\
\text { environments. }\end{array}$ & \\
\hline $\begin{array}{l}\text { Abiotic-stress tolerance } \\
\text { index (ATI) }\end{array}$ & $\begin{array}{l}{[(Y p-Y s) /(-\overline{Y p} / \bar{Y} s)]} \\
x[\sqrt{ }(Y p+Y s)]]\end{array}$ & $\begin{array}{l}\text { In combination with SSPI, can separate } \\
\text { relative tolerant and non tolerantgeno- } \\
\text { types. Lower values preferred. }\end{array}$ & \\
\hline $\begin{array}{l}\text { Modified stress tolerance } \\
\text { index (KiSTI1, 2) }\end{array}$ & $\begin{array}{l}\mathrm{K}_{1}=Y p 2 / \bar{Y} p^{2} \\
\mathrm{~K}_{2}=Y s^{2} / Y s^{2}\end{array}$ & $\begin{array}{l}\mathrm{K}_{1} \text { and } \mathrm{K}_{2} \text { are the optimal selec- } \\
\text { tion indices for stress and non-stress } \\
\text { conditions, respectively. High values } \\
\text { preferred. }\end{array}$ & Naderi et al., 2000. \\
\hline
\end{tabular}

${ }^{*} Y s$ and Yp are the yields of genotypes understress and non-stress conditions; $\bar{Y} \mathrm{~s}$ and $\bar{Y}$ pare the meanyields over all genotypes under stress and non-stressconditions

recorded with SPAD-502 Plus. Chlorophyll Stability Index (CSI) was estimated using the method developed by Kaloyereas (1958) and modifications suggested by Murty and Majumder (1962). Excised Leaf Water Loss (ELWL) was estimated as per the method suggested by Dedio (1975) and expressed as g $\mathrm{g}^{-1}$. Rate of Excised Leaf Water Loss (RLWL) was estimated as per the method suggested by Clarke (Clarke and TownleySmith, 1986) and expressed as $\mathrm{g} \mathrm{g}^{-1} \mathrm{~h}^{-1}$.

\subsection{Statistical analysis}

Keeping the complexity of organizing the field trial and using randomized designs, strip design was used for laying out the experiment, without replications. In randomized trials, the design assumes that all treatments respond similarly regardless of field conditions, which is not true in the case of the present study. It is not uncommon to find studies that involve no replications and ecological studies are impossible to have replications (Machado and Petrie, 2006). The metric parameters associated to the ten genotypes $(n=10)$ were compared between two environments, using the student t-test at 0.05 significance level. The overall linear association between any two traits was explored using the correlation coefficients and scatter plots. Cluster analysis of the genotypes was conducted using K-means clustering (SPSS 10 for windows). The relationships among different traits, soil moisture and genotypes were analyzed through multivariate analysis and biplot using R-software. This relation between genotypes and the stress-tolerant attributes could be presented in the same graph using this approach. The biplot is a useful tool for data analysis and allows the visual assessment of the structure of a 


\begin{tabular}{|c|c|c|c|c|c|c|c|c|c|c|c|c|c|}
\hline \multirow[t]{2}{*}{ Sl. no. } & \multirow[t]{2}{*}{ Entry } & \multicolumn{2}{|c|}{$\begin{array}{l}\text { Plant height } \\
\quad(\mathrm{cm})\end{array}$} & \multicolumn{2}{|c|}{$\begin{array}{c}\text { No. of } \\
\text { primary } \\
\text { branches }\end{array}$} & \multicolumn{2}{|c|}{$\begin{array}{c}\text { No. of } \\
\text { secondary } \\
\text { branches }\end{array}$} & \multicolumn{2}{|c|}{$\begin{array}{c}\text { No. of days to } \\
\text { flower } \\
\text { initiation } \\
\end{array}$} & \multicolumn{2}{|c|}{$\begin{array}{c}\text { Days to } \\
\text { completion of } \\
\text { lowering } \\
\end{array}$} & \multicolumn{2}{|c|}{$\begin{array}{l}\text { Days to } \\
\text { maturity }\end{array}$} \\
\hline & & NS & S & NS & $\mathrm{S}$ & NS & $\mathrm{S}$ & NS & $\mathrm{S}$ & NS & $\mathrm{S}$ & NS & $\mathrm{S}$ \\
\hline 1. & LCC-143 & 66.0 & 53.4 & 7.8 & 7.8 & 11.4 & 11.8 & 36 & 36 & 76.7 & 71.0 & 91.0 & 86.0 \\
\hline 2. & LCC-150 & 62.1 & 49.2 & 8.0 & 8.2 & 13.2 & 13.4 & 40 & 40 & 77.0 & 76.0 & 90.0 & 86.0 \\
\hline 3. & LCC-159 & 67.7 & 54.4 & 8.8 & 8.2 & 12.6 & 13.0 & 36 & 36 & 77.3 & 70.0 & 89.0 & 80.0 \\
\hline 4. & LCC-164 & 63.4 & 50.4 & 8.2 & 8.4 & 12.2 & 12.6 & 40 & 30 & 76.0 & 74.0 & 90.0 & 83.9 \\
\hline 5. & LCC-183 & 66.4 & 53.2 & 8.1 & 8.0 & 13.1 & 13.4 & 36 & 36 & 76.3 & 74.0 & 92.0 & 88.0 \\
\hline 6. & LCC-184 & 74.9 & 61.1 & 8.2 & 8.2 & 13.0 & 13.4 & 40 & 36 & 77.3 & 76.0 & 91.0 & 81.0 \\
\hline 7. & LCC-187 & 68.1 & 56.0 & 8.0 & 8.0 & 13.6 & 14.2 & 40 & 40 & 77.7 & 70.0 & 91.0 & 86.0 \\
\hline 8. & LCC-200 & 65.9 & 53.2 & 8.2 & 8.0 & 10.2 & 10.6 & 40 & 36 & 77.7 & 74.0 & 91.0 & 86.0 \\
\hline 9. & Sadhana & 70.9 & 58.8 & 8.0 & 7.8 & 12.7 & 13.4 & 36 & 36 & 78.0 & 72.0 & 93.0 & 88.0 \\
\hline 10. & Swathi & 66.5 & 54.5 & 7.8 & 7.6 & 10.8 & 11.2 & 40 & 38 & 77.0 & 73.0 & 92.0 & 89.0 \\
\hline Mean & & 67.2 & 54.4 & 8.1 & 8.0 & 12.3 & 12.7 & 38.4 & 36.4 & 77.1 & 73.0 & 91.0 & 85.4 \\
\hline $\begin{array}{l}\text { Confidence } \\
\text { level }(95 \%)\end{array}$ & & & 3.3 & & 0.1 & & 0.5 & & 1.1 & & 1.2 & & 1.6 \\
\hline T-stat & & & 69.47 & & 1.22 & & -9.50 & & 1.94 & & 5.28 & & 7.98 \\
\hline P-two-tail & & & 0.00001 & & 0.1266 & & 0.00001 & & 0.0424 & & 0.0003 & & 0.00001 \\
\hline $\begin{array}{l}\text { Standard } \\
\text { deviation }\end{array}$ & & & 7.4 & & 0.3 & & 1.1 & & 2.6 & & 2.6 & & 3.6 \\
\hline
\end{tabular}

NS: Non-stressed; S: Stressed

large two-way data matrix. The principal component analysis (PCA) was used to display the genotype by trait two way data in biplot. The PCA analysis is used to explain the variancecovariance structure through a few linear combinations of the original variables, to reveal the underlying relationships and interpret accrued data in a sophisticated way. The PCA and Biplot analyses were carried out with R-3.1.1 software (Chambers, 2008) for windows using the method as suggested by Jolliffe (2005).

\section{Results and Discussion}

\subsection{Changes in the soil moisture regime}

The soil moisture till the vegetative phase was similar in two blocks, however, changed rapidly in the second block from active vegetative phase i.e. after 30 DAS (Figure 1 and 2). The rapid depletion of soil moisture caused moderate stress on the plants that are evaluated in the second block giving opportunity to test their performance under dissimilar soil moisture regimes. At the time of active vegetative phase and flowering, the stressed block contained $14.5 \%$ less soil moisture content than the unstressed block. At the time of grain filling and maturity, the stressed block contained $16 \%$ less soil moisture content than the unstressed block. The stress period covered the period of active vegetative growth, initiation and growth of branches, flowering, fruit set and filling and maturity facilitating fruitful comparison the genotypes in two moisture regimes. It also helped to understand the genotype expression under moisture stress conditions. The Stress Index computed was 0.36 , which clearly indicated the genotypes underwent moderate stress corroborating the soil moisture stress conditions.

\subsection{Changes in the phenology of the genotypes}

The paired t-test revealed that there were significant differences in the observed traits under deficit moisture regime except for the number of secondary branches and test weight of the grain. As predicted the plant height, number of primary branches, no of days to flower, number of days to flower initiation and completion of flowering, days to maturity, number of umbels per plant, number of fruits plant ${ }^{-1}$, biomass and yield were significantly different from the stressed environment as indicated by the respective t-stat values and p-two tail values. However, the stress did not influence the number of secondary branches and test weights. These are the traits may probably be affected under severe stress whereas other traits are easily influenced by the prevailing moisture stress. Moisture stress after one month affected the number of umbels per plant and 


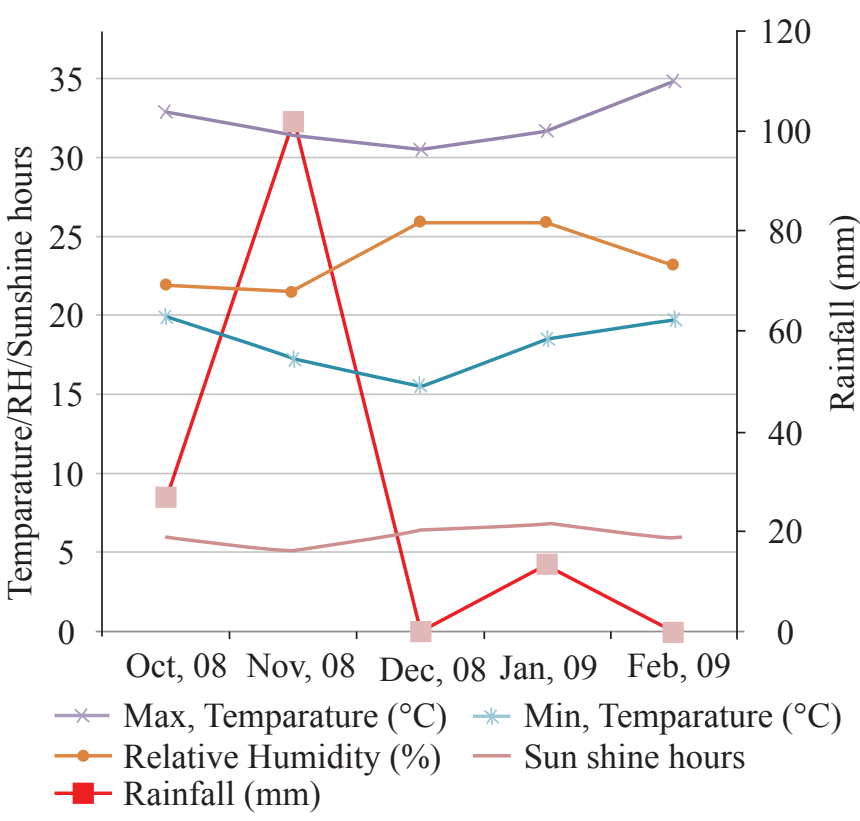

Figure 1: Monthly weather data during the experimental period at Guntur

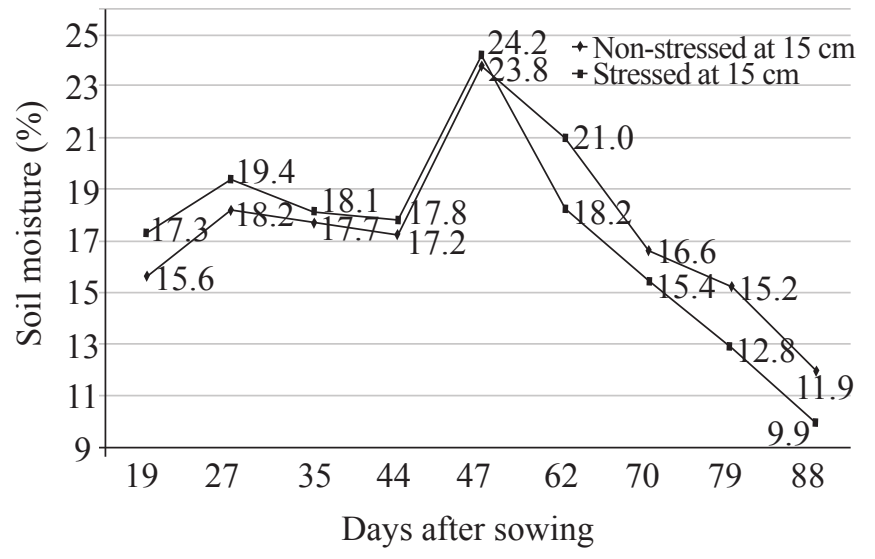

Figure 2: Soil moisture (\%) at $15 \mathrm{~cm}$ soil depth $(\mathrm{SI}=0.36)$

number of green leaves on the plant indicating the receding sink under mid-season moisture stress. The mid-season stress also induced early flowering, earlier 50\% flowering and early maturity in all the genotypes. Kanagadhileepan and Thangaraj (2002) reported similar changes in coriander genotypes subjected to moisture stress by withholding irrigation for 7 weeks.

\subsection{Changes in the biomass and yield}

As predicted, the yield and biomass were also affected by the lower soil moisture regime. However, the performance of genotypes varied in lower moisture regime. On average moisture stress effected a biomass reduction of $27.9 \%$. The mean biomass loss $(\mathrm{M}=19.9, \mathrm{SD}=1.8, \mathrm{~N}=10)$ was significantly lower than the Non-stressed environment, t $(9)=5.84$, twotail $p=0.0001$, indicating that the midseason and terminal moisture stress affected the biomass severely. The mean biomass reduction at 95\% Confidence Interval was 19.9, 19.9 g plant ${ }^{-1}$, indicating that moderate midseason and terminal moisture stress may cause yield reduction of $25.9 \%$ to $30.2 \%$. Similarly, the mean yield loss ( plan $\left.^{-1}\right)(\mathrm{M}=2.2, \mathrm{SD}=1.6, \mathrm{~N}=10)$ was significantly lower than the Non-stressed environment, $\mathrm{t}(9)=0.7$, two-tail $p=0.0012$, revealing that the midseason and terminal moisture stress affected the yield severely. The mean yield reductionat 95\% Confidence Interval was 1.7, 2.2 g plant ${ }^{-1}$, indicating that moderate midseason and terminal moisture stress may cause yield reduction of $22.7 \%$ to $24.7 \%$. A perusal of the above data indicated that the change in biomass is almost proportional to the yield loss in the genotype. There was a significant lowering of the sink in the affected plants, as indicated by the biomass reduction, thus affecting the grain yield of the plants. Jamali and Martirosyan (2013) observed that the water deficit had significant effect on seed weight, weight per plant, 1000 seed weigh, plant height and yield in coriander.

\subsection{Performance of genotypes}

The mid-season stress induced early flowering, earlier $50 \%$ flowering and early maturity in all the genotypes (Table 3 ). Vanparys (1997) reported the effect of heat and drought on the shooting of fennel and showed that moisture stress induced very early flowering. He also reported early bolting in genotypes varied between 0 to $92 \%$ revealing differential expression of genotypes regarding flowering under stress.

The yield and biomass were also affected by the soil moisture regimes in all the genotypes. However, the genotypes varied in their performance for yield and biomass. The minimum change in the biomass was recorded in LCC-150 (3.0\%) followed by LCC-143 (10.1\%) and LCC-183 (11.4\%). The maximum reduction in biomass was recorded in Swathi (44.5\%) followed by LCC-184 (40.3\%), LCC-187 (40.1\%) and LCC-159 (37.5\%). The most popular variety Sadhana recorded a biomass reduction of $31.9 \%$. The maximum yield reduction was observed in the checks Sadhana (56.6\%) and Swathi (50.6\%) indicating that these are highly susceptible to midseason stress. Minimum yield reduction was observed in LCC-150 (0\%), LCC-143 (2.4\%) and LCC-200 (3.7\%) indicating that these entries performed well under midseason stress. Kanagadhileepan and Thangaraj (2002) reported such variation among the coriander genotypes when subjected to moisture stress during the crop growth period.

The K-means clustering of the entries revealed that they formed five distinct clusters under non-stress and stressed conditions (Figure 3 and 4). The superior cluster under stressed conditions included LCC-150, LCC-143 and LCC-200. The strategies adopted by each superior entry differed greatly. LCC-150 showed a minimum biomass reduction, moderate reduction in 
the number of umbels plant ${ }^{-1}(16 \%)$, early maturity (4.4 days) and moderate reduction in the number of fruits plant ${ }^{-1}(18.9 \%)$. The entry also showed efficient partition of sink to yield as indicated by improved test weight of grains (32.4\%) under stress. However, LCC-143 adopted a different strategy by less reduction in umbels per plant $(10.4 \%)$, earlier completion of flowering (5.7 days early), early maturity (5 days), moderate reduction in biomass $(10.1 \%)$, moderate reduction in fruits plant $^{-1}(27.1 \%)$ and retention of test weight of grains $(0.2 \%$ reduction in test weight). LCC-200 had shown different adaptive strategies by earlier completion of flowering (4.7 days) and maturity (5.5 days), severe reduction in the number of umbels plant ${ }^{-1}(37.5 \%)$, moderate reduction in biomass $(22.7 \%)$, retention of almost the same number of fruits plant ${ }^{-1}$

\begin{tabular}{|c|c|c|c|c|c|c|c|c|c|c|c|c|c|}
\hline \multirow[t]{2}{*}{ Sl. no. } & \multirow[t]{2}{*}{ Entry } & \multicolumn{2}{|c|}{$\begin{array}{l}\text { Number of } \\
\text { green leaves } \\
\text { at } 75 \mathrm{DAS}\end{array}$} & \multicolumn{2}{|c|}{$\begin{array}{c}\text { Number of } \\
\text { umbels plant }{ }^{-1}\end{array}$} & \multicolumn{2}{|c|}{$\begin{array}{l}\text { Number of } \\
\text { fruits plant }^{-1}\end{array}$} & \multicolumn{2}{|c|}{ Test weight (g) } & \multicolumn{2}{|c|}{ Biomass (g) } & \multicolumn{2}{|c|}{$\begin{array}{c}\text { Yield } \\
\left(\mathrm{g} 5 \text { plant }^{-1}\right)\end{array}$} \\
\hline & & NS & $S$ & NS & $\mathrm{S}$ & NS & $\mathrm{S}$ & NS & $\mathrm{S}$ & NS & $\mathrm{S}$ & NS & $\mathrm{S}$ \\
\hline 1. & LCC-143 & 9.6 & 6.2 & 30.1 & 27.0 & 528 & 385 & 21.3 & 21.3 & 73.2 & 65.8 & 8.4 & 8.2 \\
\hline 2. & LCC- 150 & 9.4 & 6.1 & 32.4 & 27.2 & 454 & 368 & 16.7 & 22.1 & 66.8 & 64.8 & 8.0 & 7.9 \\
\hline 3. & LCC-159 & 8.8 & 7.1 & 28.7 & 17.4 & 573 & 225 & 14.3 & 21.6 & 74.2 & 46.4 & 8.2 & 4.8 \\
\hline 4. & LCC-164 & 9.2 & 6.8 & 28.0 & 16.0 & 483 & 306 & 18.4 & 22.2 & 74.5 & 48.2 & 8.8 & 6.7 \\
\hline 5. & LCC-183 & 10.1 & 7.2 & 31.0 & 25.4 & 499 & 278 & 16.5 & 21.9 & 70.2 & 62.2 & 8.2 & 6.0 \\
\hline 6. & LCC-184 & 11.2 & 8.2 & 28.7 & 17.6 & 482 & 229 & 16.4 & 21.9 & 72.4 & 43.2 & 7.9 & 4.8 \\
\hline 7. & LCC-187 & 11.2 & 8.8 & 31.3 & 20.6 & 526 & 284 & 15.2 & 22.3 & 74.8 & 44.8 & 8.0 & 6.2 \\
\hline 8. & LCC-200 & 11.8 & 8.9 & 26.9 & 16.8 & 357 & 366 & 23.2 & 21.9 & 68.8 & 53.2 & 8.2 & 7.9 \\
\hline 9. & Sadhana & 9.8 & 6.3 & 28.4 & 17.0 & 581 & 272 & 14.3 & 13.1 & 70.2 & 47.8 & 8.3 & 3.6 \\
\hline 10. & Swathi & 9.6 & 6.2 & 29.4 & 18.0 & 358 & 182 & 21.8 & 21.7 & 68.8 & 38.2 & 7.7 & 3.8 \\
\hline Mean & & 10.1 & 7.2 & 29.5 & 20.3 & 484 & 290 & 17.8 & 21.0 & 71.4 & 51.5 & 8.2 & 6.0 \\
\hline $\begin{array}{l}\text { Confidence } \\
\text { level }(95 \%)\end{array}$ & & 0.8 & & 2.52 & & 53.7 & & 1.5 & & 5.4 & & & 0.7 \\
\hline T-stat $(n=50)$ & & 15.91 & & 8.98 & & 5.85 & & -2.92 & & 5.84 & & & 4.19 \\
\hline P-two-tail & & 0.0001 & & 0.0001 & & 0.0001 & & 0.0085 & & 0.0001 & & & 0.0012 \\
\hline $\begin{array}{l}\text { Standard } \\
\text { deviation }\end{array}$ & & 1.8 & & 5.8 & & 122.4 & & 3.4 & & 12.3 & & & 1.6 \\
\hline
\end{tabular}

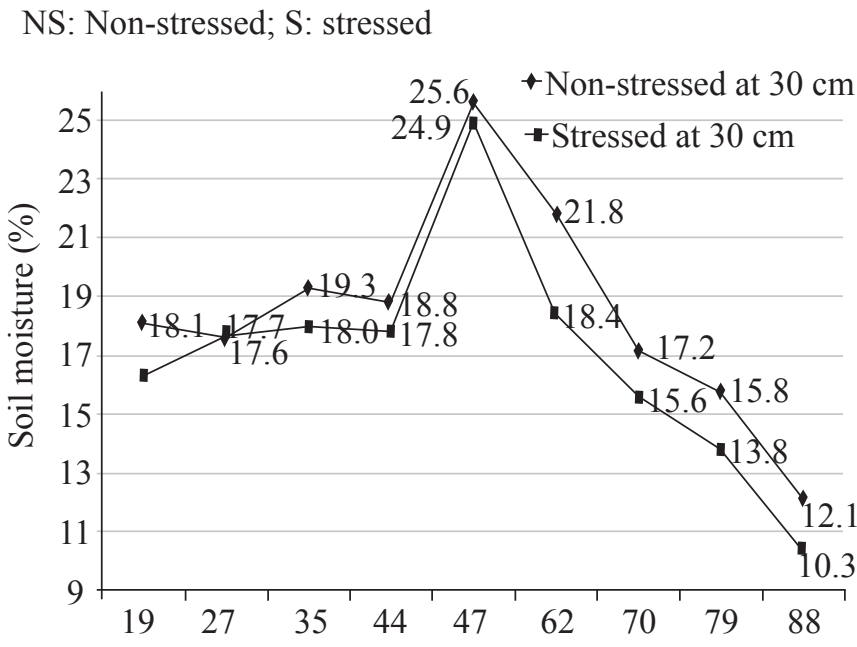

Days after sowing

Figure 3: Soil moisture (\%) at $30 \mathrm{~cm}$ soil depth $(\mathrm{SI}=0.36)$

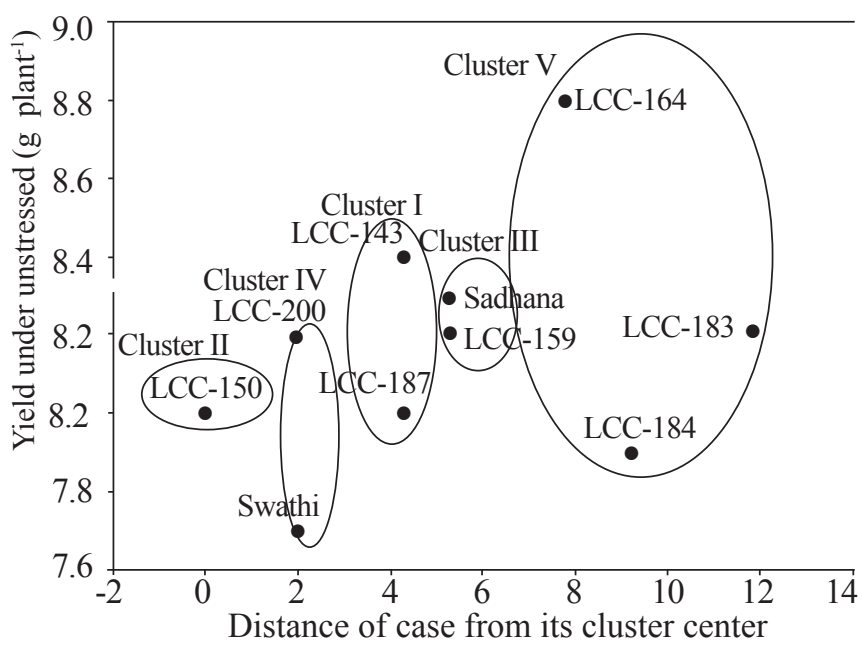

Figure 4: K-means clustering of genotypes evaluated under unstressed conditions* 
(2.5\% more) with slight reduction in test weight (5.6\%), thus achieving similar yields as unstressed environment (only 3.7\% yield loss). The popular check Sadhana though retained more number of green leaves plant ${ }^{-1}$ during the flowering period, earlier completion of flowering (early by 6 days) and early maturity (early by 5.4 days), there was a severe reduction in the number of umbels per plant (40.1\%), biomass (31.9\%), number of fruits per plant (53.2\%) and with only slight improvement in test weight of the grains (8.2\%) causing a severe reduction in yield (57.1\%).

Another remarkable entry LCC-159, retained more number of green leaves during stress period. The entry was early to complete flowering (7.3 days early) and early to mature (10.1 days early). It showed a severe reduction in biomass (37.5\%), number of umbels $(39.3 \%)$, number of fruits plant ${ }^{-1}(60.7 \%)$ and test weight (50.8\%). Though the genotype had a higher sink even under stressed environment and early, it was a poor partitioner of sink to source thus recording very low yield under stressed environment.

Understanding how a genotype counters moisture stress is a very important window for developing new drought tolerant varieties. Karpov et al. (1990) described a hybrid of coriander which tolerated spring drought and explained in detail why this hybrid was drought tolerant than others. Most of the reviews (Ashley, 1993; Subbarao et al., 1995) have brought together the available knowledge on different aspects of drought tolerance in crop plants and options to minimize yield losses due to drought. Major differences among and within crop species have been reported and different strategies to breed drought-tolerant varieties have been suggested (Blum, 1985; Walker and Miller, 1986; Arraudeau, 1989; Acevedo and Ceccarelli, 1989). The K-means clustering varied under stressed and unstressed environments. Genotypes joined new clusters under moisture stress conditions. This fact further bolsters the aforementioned conclusion that the behaviour and stress countering mechanisms of coriander genotypes varied much. This further emphasizes the need to understand the biochemical mechanisms underlying such different stress adaptive behaviours.

\subsection{Resistance/tolerance indices under stress and non-stress condition}

The grain yields of genotypes under stress and non-stress conditions were used to investigate suitable stress resistance indices for screening of cultivars under moisture stress condition, for calculating different sensitivity and tolerance indices (Table 4). Based on the stress tolerance index (STI), MP, GMP, YI, SSPI, K1STI, K2STI and grain yield in two conditions, LCC-143, LCC-150 and LCC-200 were found moisture stress tolerant with highest STI under non-stressed condition. The popular varieties used as checks i.e. Sadhana and Swathi were identified as sensitive to moisture stress with low STI values. The YSI and RDI indices indicated the genotypes LCC-143, LCC-150 and LCC-200 as the most relatively tolerant ones while for this indices and the checks Sadhana and Swathi were the least tolerant. So, according to SSI and TOL indices indicate the superiority of LCC143, LCC-150 and LCC-200 as the most relatively tolerant genotypes while genotypes Sadhana, Swathi and LCC-159 were the least relative tolerant. Considering the other tolerant indices such as YI, DI, SSPI, ATI, SNPI also indicated the superiority of LCC-143, LCC-150 and LCC-200 as tolerant ones among the tested genotypes. The ATI values revealed that the genotypes LCC-150, LCC-143 and LCC-200 were the most tolerant, whereas Sadhana, LCC-159, Swathi and LCC-184 were most susceptible forming the set of extreme parents for crop improvement studies. The SSPI values in association with ATI corroborated the extreme parent set of above entries, which is quite useful for further research. The higher SNPI values of the entries LCC-150, LCC-143 and LCC-200 indicated these were stable yielders in both stressed and non-stressed environments whereas the entries Swathi, Sadhana, LCC-159 with low SNPI values were the most unstable. As the SNPI values indicate relative resistance, the above genotypes may be considered relatively superior in the test genotype group. Golabadi et al. (2006) used MP, GMP, TOL, SSI and ST for discriminating $\mathrm{F}_{3}$ and $\mathrm{F}_{4}$ wheat lines. Farshadfar et al. (2012) used the tolerance indices such as, RDI, STI, YSI, SSPI, and MSTI for screening tolerance bread wheat land races. Khalili et al. (2012) used these parameters to screen canola cultivars where as Naghavi et al. (2013) used these for screening Corn cultivars. Moosavai et al. (2008) demonstrated the utility of all these parameters in stress research while screening drought tolerance and resistance in wheat genotypes. El-Mohsen et al. (2015) evaluated bread wheat genotypes and opined that these parameters are highly effective in discriminating genotypes against drought.

\subsection{Physiological parameters of drought}

Eight physiological parameters recorded, showed considerable variation among the genotypes (Table 5). Highest RWC was recorded in the genotype LCC-159 (78.3\%), which showed higher water balance in the plant, where as lowest, was recorded in the genotype Swathi (71.4\%). The SLW which indicates the ability of the plant to produce biomass under stress condition was highest in the genotype LCC-143, whereas it was lowest in Swathi indicating its inability to survive under stress conditions. SCMR values, which indicate high chlorophyll content, were higher in the checks Sadhana and Swathi (35.9 and 33.8 respectively). However, the CSI values which indicate 


\begin{tabular}{|c|c|c|c|c|c|c|c|c|c|c|c|c|c|c|c|c|c|c|}
\hline $\begin{array}{l}\text { Sl. } \\
\text { no. }\end{array}$ & Entry & Yp & Ys & TOL & MP & GMP & $\begin{array}{l}\text { HA } \\
\text { RM }\end{array}$ & STI & RDI & SSI & YI & DI & YSI & SSPI & $\begin{array}{l}\mathrm{k}_{1} \\
\text { STI }\end{array}$ & $\begin{array}{c}\mathrm{k}_{2} \\
\text { STI }\end{array}$ & ATI & SNPI \\
\hline 1. & LCC-143 & 8.4 & 8.2 & 0.2 & 8.30 & 8.30 & 8.30 & 1.03 & 1.33 & 0.09 & 1.37 & 1.34 & 0.98 & 1.67 & 1.06 & 1.87 & 0.60 & 36.06 \\
\hline 2. & LCC-150 & 8.0 & 7.9 & 0.1 & 7.95 & 7.95 & 7.95 & 0.95 & 1.35 & 0.05 & 1.32 & 1.30 & 0.99 & 0.83 & 0.96 & 1.74 & 0.29 & 42.98 \\
\hline 3. & LCC-159 & 8.2 & 4.8 & 3.4 & 6.50 & 6.27 & 6.06 & 0.59 & 0.80 & 1.55 & 0.80 & 0.47 & 0.59 & 28.38 & 1.01 & 0.64 & 8.99 & 8.97 \\
\hline 4. & LCC-164 & 8.8 & 6.7 & 2.1 & 7.75 & 7.68 & 7.61 & 0.88 & 1.04 & 0.89 & 1.12 & 0.85 & 0.76 & 17.53 & 1.16 & 1.25 & 6.06 & 14.29 \\
\hline 5. & LCC-183 & 8.2 & 6.0 & 2.2 & 7.10 & 7.01 & 6.93 & 0.73 & 1.00 & 1.01 & 1.00 & 0.73 & 0.73 & 18.36 & 1.01 & 1.00 & 6.08 & 12.40 \\
\hline 6. & LCC-184 & 7.9 & 4.8 & 3.1 & 6.35 & 6.16 & 5.97 & 0.56 & 0.83 & 1.47 & 0.80 & 0.49 & 0.61 & 25.88 & 0.93 & 0.64 & 8.10 & 9.07 \\
\hline 7. & LCC-187 & 8.0 & 6.2 & 1.8 & 7.10 & 7.04 & 6.99 & 0.74 & 1.06 & 0.84 & 1.04 & 0.80 & 0.78 & 15.03 & 0.96 & 1.07 & 4.97 & 13.44 \\
\hline 8. & LCC-200 & 8.2 & 7.9 & 0.3 & 8.05 & 8.05 & 8.05 & 0.96 & 1.31 & 0.14 & 1.32 & 1.27 & 0.96 & 2.50 & 1.01 & 1.74 & 0.88 & 30.17 \\
\hline 9. & $\begin{array}{l}\text { Sadhana } \\
\text { (c) }\end{array}$ & 8.3 & 3.6 & 4.7 & 5.95 & 5.47 & 5.02 & 0.44 & 0.59 & 2.12 & 0.60 & 0.26 & 0.43 & 39.23 & 1.03 & 0.36 & 11.89 & 6.48 \\
\hline 10. & Swathi(c) & 7.7 & 3.8 & 3.9 & 5.75 & 5.41 & 5.09 & 0.44 & 0.67 & 1.90 & 0.63 & 0.31 & 0.49 & 32.55 & 0.89 & 0.40 & 9.70 & 6.90 \\
\hline $\mathrm{Me}$ & & 8.17 & 5.99 & 2.18 & 7.08 & 6.93 & 6.80 & 0.73 & 1.00 & 1.01 & 1.00 & 0.78 & 0.73 & 18.20 & 1.00 & 1.07 & 5.76 & 18.07 \\
\hline & & 0.30 & 1.70 & 1.62 & 0.92 & 1.07 & 1.21 & 0.22 & 0.27 & 0.75 & 0.28 & 0.41 & 0.20 & 13.51 & 0.07 & 0.57 & 4.08 & 13.26 \\
\hline
\end{tabular}

\begin{tabular}{llcccccccc}
\hline \multicolumn{7}{l}{ Table 5: } & Different physiological drought tolerant parameters \\
\hline Sl. no. & Genotype & RWC & SLW & SCMR & CSI & LT & LWP & ELWL & RLWL \\
\hline 1. & LCC-143 & 77.2 & 3.0 & 30.2 & 50.3 & 0.189 & -2.95 & 2.22 & 0.186 \\
2. & LCC-150 & 70.3 & 2.8 & 30.5 & 48.0 & 0.102 & -3.04 & 2.59 & 0.258 \\
3. & LCC-159 & 78.3 & 2.7 & 30.5 & 49.7 & 0.194 & -2.85 & 3.04 & 0.486 \\
4. & LCC-164 & 71.8 & 2.9 & 30.5 & 48.5 & 0.104 & -2.81 & 3.66 & 0.574 \\
5. & LCC-183 & 72.3 & 2.7 & 30.9 & 49.5 & 0.095 & -2.81 & 4.14 & 0.700 \\
6. & LCC-184 & 71.8 & 2.8 & 31.3 & 47.2 & 0.100 & -2.51 & 2.69 & 0.228 \\
7. & LCC-187 & 77.3 & 2.5 & 26.0 & 48.9 & 0.105 & -2.75 & 2.75 & 0.308 \\
8. & LCC-200 & 76.5 & 2.6 & 30.0 & 54.3 & 0.106 & -2.20 & 3.69 & 0.609 \\
9. & Sadhana (c) & 72.8 & 2.5 & 35.9 & 48.3 & 0.096 & -2.53 & 3.44 & 0.334 \\
10. & Swathi (c) & 71.4 & 2.4 & 33.8 & 46.5 & 0.091 & -2.76 & 3.35 & 0.419 \\
Mean & & 73.97 & 2.69 & 30.96 & 49.12 & 0.12 & -2.72 & 3.16 & 0.41 \\
Standard deviation & 2.98 & 0.18 & 2.56 & 2.15 & 0.04 & 0.25 & 0.60 & 0.18 \\
\hline
\end{tabular}

RWC: Relative Water Content (\%) at 75 DAS; SLW: Specific Leaf Weight $\left(\mathrm{mg} \mathrm{cm}^{-2}\right)$; SPAD: SCMR reading; Leaf thickness (mm); LWP: Leaf water potential (mPascals); ELWL: Excised leaf water loss $\left(\mathrm{g} \mathrm{g}^{-1}\right)$; RLWL: Rate of excised leaf water Loss $\left(\mathrm{g} \mathrm{g}^{-1} \mathrm{~h}^{-1}\right)$

chlorophyll stability under stress conditions indicated the genotypes LCC-200 (54.3) and LCC-143 (50.3) were desired genotypes. LT values were higher for the genotypes LCC$159(0.194 \mathrm{~mm})$ and LCC-143 $(0.189 \mathrm{~mm})$ indicating the ability of these genotypes tolerating the moisture stress. The LWP (mPascals) measured was lowest in LCC-200 (-2.20 mPascals) followed by LCC-184 (-2.51 mPascals) indicating efficient water use by these genotypes. The ELWL $\left(\mathrm{g} \mathrm{g}^{-1}\right)$, which indicates the plants ability sustain water loss indicated the genotypes LCC-143 (2.22 $\left.\mathrm{g} \mathrm{g}^{-1}\right)$ followed LCC-150 (2.59 $\left.\mathrm{g} \mathrm{g}^{-1}\right)$. The RLWL, which indicates relative efficacy of water balancing in leaf indicated that the genotypes LCC-143 $(0.186$ $\left.\mathrm{g} \mathrm{g}^{-1} \mathrm{~h}^{-1}\right)$ followed by LCC-184 $\left(0.228 \mathrm{~g} \mathrm{~g}^{-1} \mathrm{~h}^{-1}\right)$ were superior.

\subsection{Principal component analysis}

The PCA of the yield under stressed and non-stressed conditions was taken up the resulting biplots are presented in Figure 5 and 6 representing drought indices and physiological drought parameters respectively. The biplot (s) derived from various drought indices (Figure 5), explained the 98.8\% variation, $91.33 \%$ by the Principal Component I (Dim 1) and $7.49 \%$ by Principal Component II (Dim II). As expected, Yp 

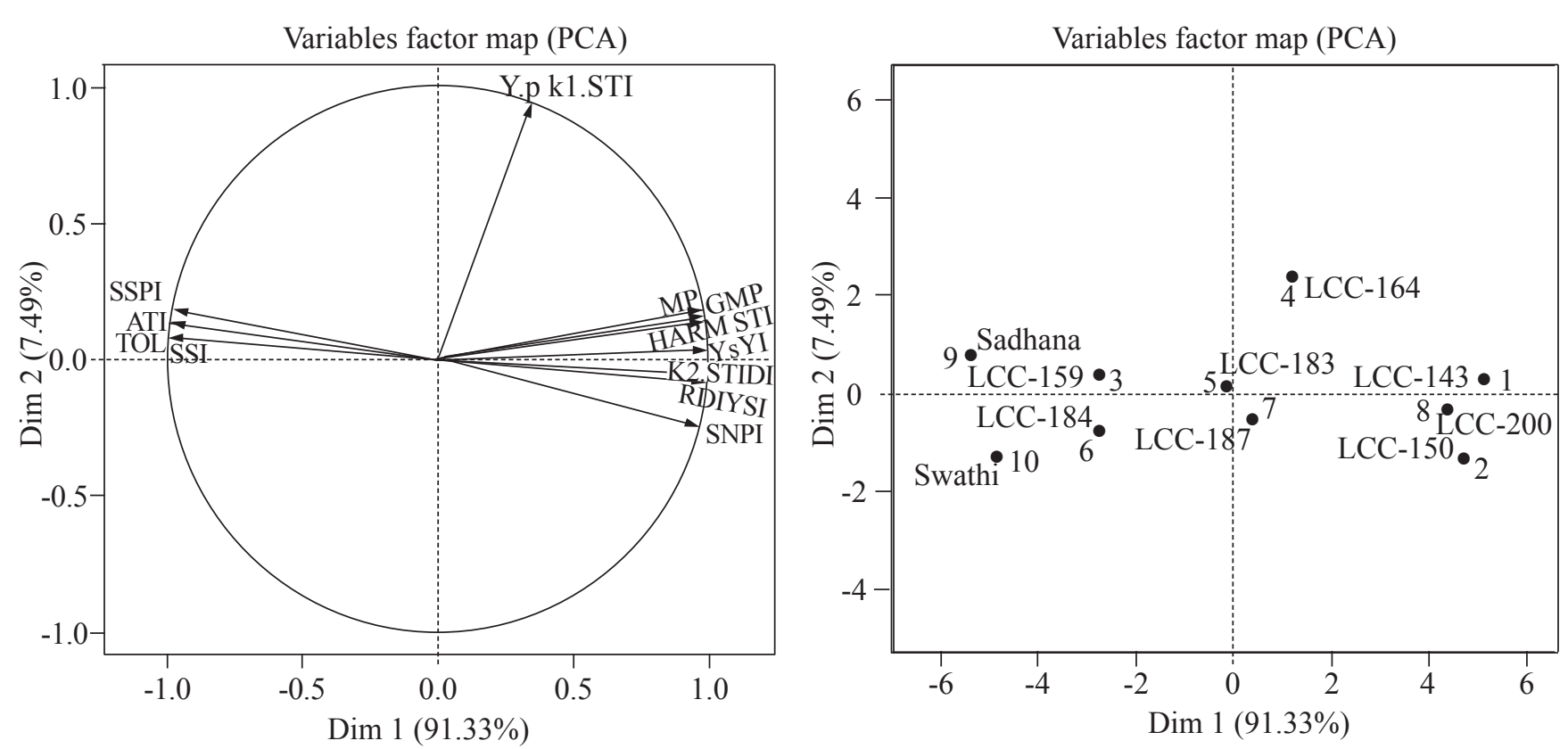

Figure 5: Variable and Individual factor map for all genotypes $(\mathrm{n}=10)$ by PCA analysis for various drought indices
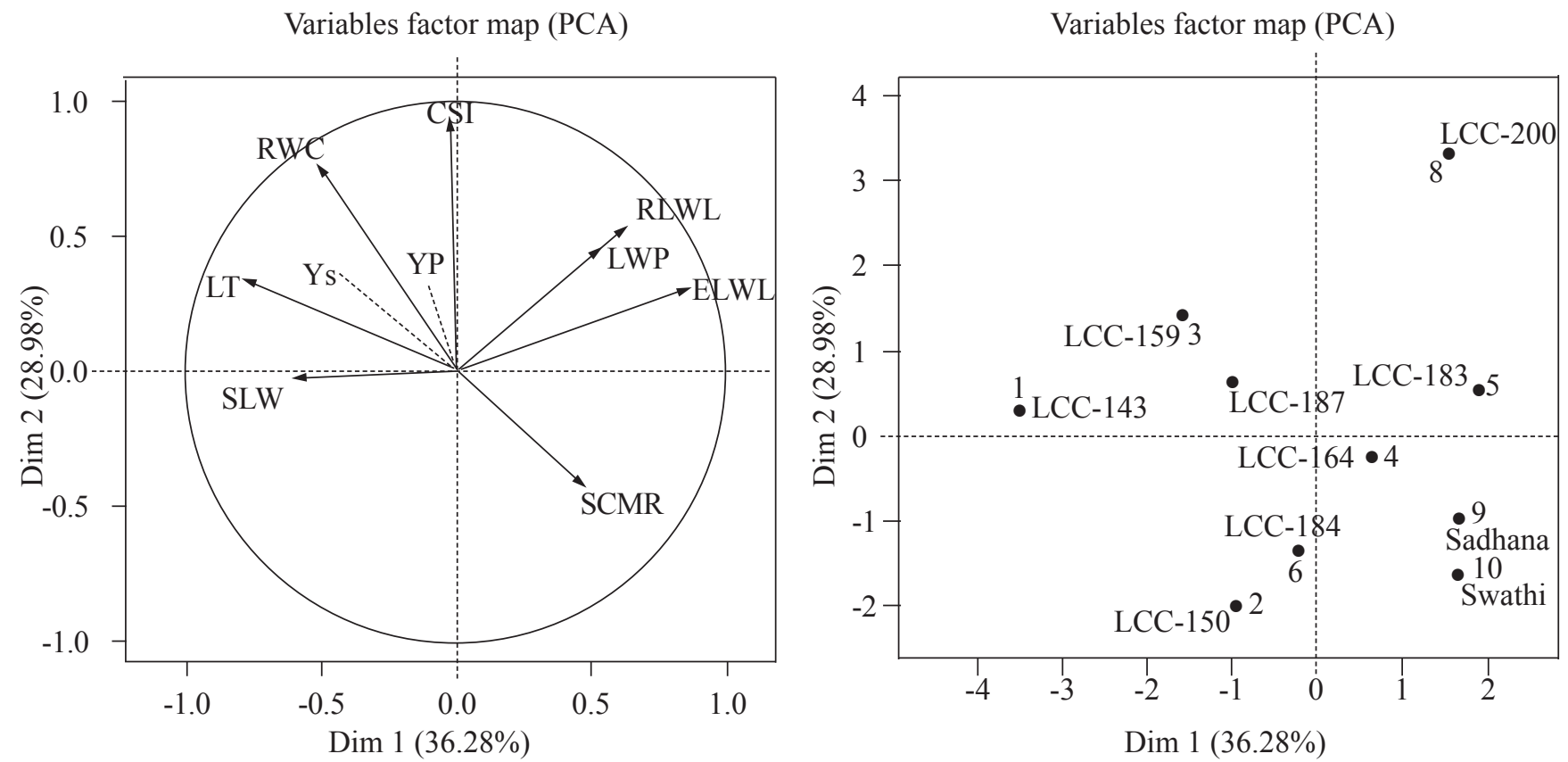

Figure 6: Variable and Individual factor map for all genotypes $(\mathrm{n}=10)$ by PCA analysis for various physiological drought parameters

and K1STI were highly correlated and almost independent of all other parameters, as indicated by the direction of the arrows. All the drought indices along with Yp and Ys varied considerably among genotypes as indicated by the length of arrows of the parameters. The indices ATI, TOL, SSI and SSPI were correlated as indicated by direction and angle of the indices. Similarly, MP, GMP, HARM, STI, K2STI, Ys, YI, DI, YSI, RDI, YI and SNPI were closely related. The Individual Factor Map indicated that the genotypes LCC-143, LCC-200 and LCC-150 were having positive correlation with the MP, GMP, HARM, STI, K2STI, Ys, YI, DI, YSI, RDI, YI and SNPI indices, thus proving to be drought tolerant ones. The biplots(s) of drought parameters (Figure 6) explained the $65.26 \%$ variation, $36.28 \%$ by the Principal Component I (Dim 1) and $28.98 \%$ by Principal Component II (Dim II). Variability among the genotypes was narrow for SLW, where as considerable variation among the genotypes was observed in other parameters. The Ys was positively correlated with RWC and LT while negatively correlated with SCMR values. The biplots indicated that the genotype LCC-143 was positively 
associated with high SLW, LCC-150 with low ELWL and RLWL and LCC-200 with high CSI and LWP values.

\section{Conclusion}

Among the coriander genotypes evaluated, LCC-150, LCC143 and LCC-200 were tolerant and may be used in crop improvement programmes for developing drought tolerant varieties. Among several drought indices evaluated, KiSTI values can be utilized for successful discrimination of drought tolerant lines as these are clearly associated with performance of the genotypes in non-stressed and stressed conditions. The genotype LCC-143 was positively associated with high SLW, LCC-150 with low ELWL and RLWL and LCC-200 with high CSI and LWP values.

\section{References}

Acevedo, E., Ceccarelli, S., 1989. Role of physiologist-breeder in a breeding program for drought resistance conditions. In: Baker, W.G. (Ed.), Drought resistance in cereals, CAB International, Wallingford, UK, 117-139.

Arraudeau, M.A., 1989. Breeding strategies for drought resistance. In: Baker, W.G. (Ed.), Drought resistance in cereals, CAB International, Wallingford, UK, 107-116.

Ashley, J., 1993. Drought and crop adaptation. In:Rowland, J.R.J. (Ed.), Dryland farming in Africa, Macmillan Press Ltd., UK, 46-67.

Barrs, H.D., Weatherley, P.E., 1962. A re-examination of the relative turgidity technique for estimating water deficits in leaves. Australian Journal of Biological Sciences 15(3), 413-428.

Blum, A., Jordan, W.R., 1985. Breeding crop varieties for stress environments. Critical Reviews in Plant Sciences 2(3), 199-238.

Bouslama, M., Schapaugh, W.T., 1984. Stress tolerance in soybeans. I. Evaluation of three screening techniques for heat and drought tolerance. Crop Science 24(5), 933-937.

Carrubba, A., la Torre, R., Saiano, F., Alonzo, G., 2006. Effect of sowing time on coriander performance in a semiarid Mediterranean environment. Crop science 46(1), 437-447.

Chambers, J., 2008. Software for data analysis: programming with R. Springer Science and Business Media, New York, United States of America.

Clarke, J.M., Townley-Smith, T.F., 1986. Heritability and relationship to yield of excised-leaf water retention in durum wheat. Crop Science 26(2), 289-292.

Dedio, W., 1975. Water relations in wheat leaves as screening tests for drought resistance. Canadian Journal of Plant Science 55(2), 369-378.

El-Mohsen, A.A.A., El-Shafi, M.A., Gheith, E.M.S., Suleiman,
H.S., 2015. Using Different Statistical Procedures for Evaluating Drought Tolerance Indices of Bread Wheat Genotypes. Advance in Agriculture and Biology 4(1), 19-30.

Farshadfar, E., Farshadfar, M., Dabiri, S., 2012. Comparison between effective selection criteria of drought tolerance in bread wheat landraces of Iran. Annals of Biological Research 3(7), 3381-3389.

Farshadfar, E., Ghannadha, M., Zahravi, M., Sutka, J., 2001. Genetic analysis of drought tolerance in wheat. Plant Breeding 114, 542-544.

Fernandez, G.C., 1992. Effective selection criteria for assessing plant stress tolerance. In: Kuo, C.G. (Ed.), Proceedings of the international symposium on adaptation of vegetables and other food crops in temperature and water stress, Adaptation of food crops to temperature and water stress. Taipei, Taiwan. 13-18 Aug., 257-270.

Fischer, R.A., Maurer, R., 1978. Drought resistance in spring wheat cultivars. I. Grain yield responses. Crop and Pasture Science 29(5), 897-912.

Fischer, R.A., Rees, D., Sayre, K.D., Lu, Z.M., Condon, A.G., Saavedra, A.L., 1998. Wheat yield progress associated with higher stomatal conductance and photosynthetic rate, and cooler canopies. Crop science 38(6), 1467-1475.

Gavuzzi, P., Rizza, F., Palumbo, M., Campanile, R.G., Ricciardi, G.L., Borghi, B., 1997. Evaluation of field and laboratory predictors of drought and heat tolerance in winter cereals. Canadian Journal of Plant Science 77(4), 523-531.

Golabadi, M., Arzani, A., Maibody, S.M., 2006. Assessment of drought tolerance in segregating populations in durum wheat. African Journal of Agricultural Research 1(5), 162-171.

Jafari, A., Paknejad, F.A.R.Z.A.D., Al-Ahmadi, M.J., 2009. Evaluation of selection indices for drought tolerance of corn (Zea mays L.) hybrids. International Journal of Plant Production 3(4), 33-38.

Jamali, M.M., Martirosyan, H., 2013. Evaluate the effect of water deficit and chemical fertilizers on some characteristics of coriander (Coriandrum sativum L.). International Journal of Agronomy and Plant Production 4(3), 413-417.

Jolliffe, I.T., 2005. Principal component analysis. John Wiley and Sons, Ltd.

Kaloyereas, S.A., 1958. A New Method of Determining Drought Resistance. Plant Physiology 33(3), 232.

Kanagadhileepan, K., Thangaraj, T., 2002. Physiological and biochemical responses of coriander genotypes to moderate drought stress conditions. South Indian Horticulture 50(4/6), 685-690. 
Karpov, G.Y., Popovtsev, I.L., Mel'nikova, V.A., 1990. Physiological and biochemical features of the drought resistance of coriander in relation to breeding problems. Trudy, VsesoyuznyiNauchno-Issledovatel'skiîInstitutĖf iromaslichnykhKul'tur 21, 40-47.

Lan, J., 1998. Comparison of evaluating methods for agronomic drought resistance in crops. Acta Agriculturae BorealiOccidentalis Sinica 7, 85-87.

Moniruzzaman, M., Rahman, M.M., Hossain, M.M., Sirajul Karim, A.J.M., Khaliq, Q.A., 2013. Effect of irrigation on seed yield and yield attributes of coriander (Coriandrum sativum L.). No. 36(1), Bulletin of the Institute of Tropical Agriculture, Kyushu University, 035-043.

Moosavi, S.S., YazdiSamadi, B., Naghavi, M.R., Zali, A.A., Dashti, H., Pourshahbazi, A., 2008. Introduction of new indices to identify relative drought tolerance and resistance in wheat genotypes. Desert 12(2), 165-178.

Murty, K.S., Majumder, S.K., 1962. Modifications of technique for determination of chlorophyll stability index in relation to studies of drought resistance in rice. Current Science 31(11), 470.

Naderi, A., Majidi-Heravan, E., Hashemi-Dezfuli, A., Rezaie, A., Nour-Mohamadi, G., 2000. Efficiency analysis of indices for tolerance to environmental stresses in field crops and introduction of a new index. Seed and Plant 15(4), Pe390-Pe402.

National Horticulture Board, 2015. First Advance Estimates for Horticulture Crops for 2015-2016 [Online] Available fromhttp://nhb.gov.in/area-pro/2015-16 ( ${ }^{\text {st }}$ Estimate). xlsx [Accessed on 29 February 2015].

Nowak, J., Szemplinski, W., 2014. Influence of sowing date on yield and fruit quality of coriander (Coriandrum sativum L.). Acta Scientiarum Polonorum Hortorum Cultus 13(2), 83-96.

Pearce, R.B., Carlson, G.E., Barnes, D.K., Hart, R.H., Hanson, C.H., 1969. Specific leaf weight and photosynthesis in alfalfa. Crop Science 9(4), 423-426.

Ramirez-Vallejo, P., Kelly, J.D., 1998. Traits related to drought resistance in common bean. Euphytica 99(2), 127-136.

Rashed, N.M., Darwesh, R.K., 2015. A comparative study on the effect of microclimate on planting date and water requirements under different nitrogen sources on coriander (Coriandrum sativum L.). Annals of Agricultural Sciences 60(2), 227-243.

Reynolds, S.G., 1970. The gravimetric method of soil moisture determination Part III An examination of factors influencing soil moisture variability. Journal of Hydrology 11(3), 288-300.

Rosielle, A.A., Hamblin, J., 1981. Theoretical aspects of selection for yield in stress and non-stress environment. Crop Science 21(6), 943-946.

Rzekanowski, C., Marynowska, K., Rolbiecki, S., Rolbiecki, R., 2008. Oddziaływaniewybranychczynnikówmeteo rologicznychnaniektóreelementyplonuczterechgatunk owziółuprawianych w warunkachdeszczowania. Acta Agrophysica 12(1), 163-171.

Schneider, K.A., Rosales-Serna, R., Ibarra-Perez, F., CazaresEnriquez, B., Acosta-Gallegos, J.A., Ramirez-Vallejo, P., Wassimi, N., Kelly, J.D., 1997. Improving common bean performance under drought stress. Crop Science 37(1), 43-50.

Sharma, B.R., Sharma, B., Rao, K.V., Vittal, K.P.R., Amarasinghe, U.A., 2006. Realizing the potential of rainfed agriculture in India. Draft prepared for the IWMICPWF Project on Strategic Analyses of India's National River-Linking Project, Colombo, Sri Lanka: International Water Management Institute.

Singh, N.P., Byjesh, K., Bantilan, C., Rao, V.U.M., Venkateswarulu, B., Niranjan, F., Jayatilaka, W., Deb, U.K., Ha, P.Q., Suddhiyam, P., Nedumaran, S., 2015. Changing Climate-Responding to the Inevitable. Climate Change Challenges and Adaptations at Farm-level: Case Studies from Asia and Africa 9, 58.

Subbarao, G.V., Johansen, C., Slinkard, A.E., Nageswara Rao, R.C., Saxena, N.P., Chauhan, Y.S., Lawn, R.J., 1995. Strategies for improving drought resistance in grain legumes. Critical reviews in plant sciences 14(6), 469-523.

Vanparys, L., 1997. Fennel: Heat and drought determine shooting. Proeftuinnieuws 7(11), 15-17.

Vile, D., Garnier, E., Shipley, B., Laurent, G., Navas, M.L., Roumet, C., Lavorel, S., Diaz, S., Hodgson, J.G., Lloret, F., Midgley, G.F., 2005. Specific leaf area and dry matter content estimate thickness in laminar leaves. Annals of botany 96(6), 1129-1136.

von Hofler, K.A.K., Migsch, H., Rottenburg, W., 1942. Über die Austrocknungsresistenz landwirtschaftlischer Kulturpflanzen, 12, 50-61.

Walker, D.W., J.C. Miller Jr., 1986. Intraspecific variability for drought resistance in cowpea. Scientia Horticulturae $29,87-100$.

Yadava, H.S., 2015. Multivariate Analysis for Umbel per plant in Land races of Coriander (Coriandrum sativum L.). Turkish Journal of Agriculture-Food Science and Technology 3(3), 117-120. 